\title{
Tinggalan Arkeologi Di Kerajaan Gowa Dan Tallo Berdasarkan Kajian Geologi Dan Lokasi Sumber Bahan
}

\author{
Fadhlan S. Intan
}

Keywords: raw materials, stone, natural resources, kingdom, sulawesi

How to Cite:

Intan, F. S. Tinggalan Arkeologi Di Kerajaan Gowa Dan Tallo Berdasarkan Kajian Geologi Dan Lokasi Sumber Bahan. Berkala Arkeologi, 15(3), 173-176. https://doi.org/10.30883/jba.v15i3.690

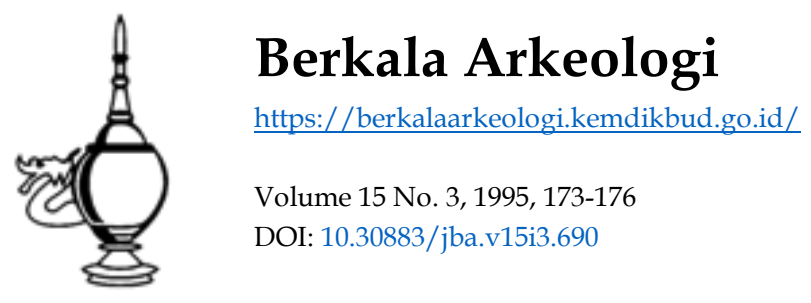

\section{(7)(2)}

This work is licensed under a Creative Commons Attribution-NonCommercialShareAlike 4.0 International License. 


\title{
TINGGALAN ARKEOLOGI DI KERAJAAN GOWA DAN TALLO BERDASARKAN KAJIAN GEOLOGI DAN LOKASI SUMBER BAHAN
}

\author{
M. Fadhlan S. Intan \\ (Pusat Penelitian Arkeologi Nasional)
}

\section{Pendahuluan}

Dalam menguraikan berbagai peninggalan kebudayaan masa lampau, ilmu Arkeologi ditunjang berbagai bidang ilmu yang dapat memecahkan segala aspek yang tercakup dalam obyek peninggalan. IImu-ilmu itu misalnya Sosiologi, Antropologi, Paleoantropologi, Etnologi, Etnografi, Kimia, Biologi, Geologi, dan untuk pengolahan data diterapkan metode statistik dan komputer.

Peranan ilmu geologi dalam kajian arkeologi begitu penting, dimana ilmu tersebut dapat menguraikan masalah yang berkaitan dengan keadaan lingkungan alam, perolehan sumber bahan baku, unsur-unsur batuan sebagai penyusun suatu bangunan kuno serta lingkungan kuno lainnya. Berdasarkan hal tersebut diatas, maka dalam tulisan ini akan diuraikan selain kondisi geologinya, juga tentang sejauh mana penggunaan dan lokasi pengambilan batuan sebagai bahan baku pada pembangunan kepurbakalaan di Kerajaan Gowa dan Tallo

Sulawesi Selatan dikenal sebagai tempat kerajaan yang cukup banyak, salah satu diantaranya adalah Kerajaan Gowa dan Tallo. Kerajaan ini amat menarik untuk dibahas, yaitu pesatnya pembangunan yang disebabkan oleh pemindahan ibukota kerajaan dengan alasan strategis. Somba Opu, Ujung Pandang dan sekitamya merupakan pusat kerajaan, berada di lengan selatan Sulawesi, yang dibatasi oleh selat Makassar di sebelah barat, Kabupaten Gowa di sebelah timur dan selatan serta Kabupaten Maros di sebelah Utara. Secara geografis daerah ini terletak pada $5^{\circ} 3^{\prime}-5^{\circ} 4^{\prime} 30^{\prime \prime}$ LS dan $119^{\circ} 20^{\prime}-119^{\circ} 24^{\prime}$ BT, serta tercantum pada peta topografi lembar $74 / X X X I V-B$; 74/XXXIV-D: 75/XXXIV-A; 75/XXXIV-C berskala 1:50.000.

\section{Geologi \\ 1. Geomorfologi}

Somba Opu dan Ujung Pandang terletak di pantai barat Sulawesi Selatan dengan keduduk-an antara 2-18 m dpl. Morfologinya merupakan dataran rendah yang relatif datar dan sebagian besar tersusun endapan aluvium.

Di bagian selatan dibatasi sungai Jeneberang dan di utara dibatasi sungai Tallo. Ke arah timur daerah ini berkembang menjadi daerah perbukitan yang tersusun oleh satuan batuan gunungapi dan satuan batupasir.
Ketinggian daerah dataran berkisar antara 2 $6 \mathrm{~m}$ dpl. Pada tempat yang rendah dijumpai rawarawa sedangkan pemukiman penduduk menempati daerah yang agak tinggi dan kering serta di tepi jalan yang menghubungkan Ujung Pandang - Sungguminasa dan jalan antara Ujung Pandang - Maros.

Sungai-sungai yang mengalir di daerah in adalah sungai Jeneberang dengan anak sungarnya sungai Jenebanda, sungai Jeneberu. Sungai Tallo dengan anak sungainya sungai Tekotata'lappak, sungai Tekolamberek, sungai Pampang. sungai Batoelatjoek dan sungai Biringromang Arah aliran kedua sungai tenggara-baratlaut

Pola aliran sungai Jeneberang dan sungaı Tallo, menyerupai urat daun, dimana anak-anak sungai menyebar dan bertemu pada satu titik, yaitu sungai Jeneberang dan sungai Tallo sebagai induk sungainya. Pola yang demikian disebut dengan pola aliran sungai Dendritik, yang merupakan ciri khas pada daerah dataran dengan litologi yang homogen (Lobeck, 1939).

Kenampakan sungai di daerah ini, dicirikan dengan adanya profil sungai berbentuk hurup " $U$ ". umumnya sudah mengalami kelokan-kelok-an sungai (meander), dijumpai adanya dataran banjir (flood plain). Berdasarkan hal ini, maka stadia sungai Jeneberang dan sungai Tallo, digolongkan kedalam sungai berstadia Dewasa (Thornbury,1964). Pesatnya proses erosi di sungai Jeneberang, dicirikan dengan adanya endapan-endapan yang terakumulasi di muara sungai dan dikenal dengan nama Delta Kaki Burung (Birds Foot Delta). Sedangkan di muara sungai Tallo belum terlihat adanya perkembangan delta.

\section{Stratigrafi}

Berdasarkan lithostratigrafi, maka daerah Somba Opu, Ujung Pandang dan sekitarnya tersusun atas 3 satuan batuan, yaitu:

\footnotetext{
a. Endapan Aluvium

Endapan aluvium terdiri dari:

Endapan Sungai, penyebarannya di jumpai di sekitar muara sungai Jeneberang dan sungai Tallo. Endapan ini terdiri dari pasir lepas berbutir halus hingga kasar, warna abu-abu kecoklatan dan terdiri dari komponen batuan gunungapi. Juga dijumpai kerikil dan kerakal, terutama di daerah agak ke hulu. Pada beberapa tempat dijum pai adanya lensa-lensa lempung yang lunak.
} 
Endapan pantai, terdiri dari pasir lepas benwama abu-abu hitam dan kecoklatan, berbutir halus hingga kasar, mengandung sisa-sisa cangkang kerang laut. Penyebarannya meliputi daerah di sepanjang pantai sampai $\pm 2 \mathrm{~km}$ dari garis pantai

Endapan Sungai Lama, terdiri dari pasir, pasir lempungan, lanau dan lempung, benwarna coklat sampai abu-abu kecoklatan. Penyebaran cukup luas, meliputi daerah dataran yang umumnya merupakan daerah persawahan, perkampungan dan sebagian merupakan rawa-rawa. Pada daerah yang berawa dijumpai lempung benwama kehitaman bercampur dengan sisa-sisa organik.

Endapan aluvium merupakan hasil pelapukan dari batuan penyusun daerah ini, serta berumur Holosen (Sukamto, 1975).

\section{b. Satuan Batuan Gunungapi}

Satuan batuan gunungapi terdiri dari tufa, tufa lapilli dan breksi. Secara umum satuan batuan ini berwarna putih kecoklatan hingga coklat. Pelapukan dari batuan ini menghasilkan tanah yang berwarna putih kecoklatan hingga coklat. Kekompakannya, dari agak kompak hingga kompak pada batuan yang masih segar. Breksi pada satuan ini mempunyai fragmen batuan beku andesit berukuran $5 \mathrm{~cm}-3 \mathrm{~m}$. Penyebarannya meliputi daerah Panaikang, Panara, Biring Romang, Bangkala dan Bukit Tamalate. Umur satauan batuan gunungapi adalah Miosen Atas - Pliosen Bawah (Sukamto, 1975).

\section{c. Satuan Batupasir}

Satuan batupasir terdiri batupasir tufaan yang berbutir halus hingga kasar diselingi oleh lapisan konglomerat. Batupasir tufaan berwarna abu-abu terang, sedang yang agak lapuk berwama kecoklatan. Berlapis dengan ketebalan perlapisan berkisar antara 20-25 cm. Sangat kompak dan mempunyai sifat gampingan. Konglomerat pada satuan ini berwama kecoklatan, mempunyai fragmen batuan beku andesit berukuran $5 \mathrm{~mm}-25 \mathrm{~cm}$ sangat kompak. Singkapan satuan batupasir ini tersingkap di dekat terminal Bis Panaikang. Kompleks PLTU Tello, sebelah utara Tamalanrea dan di sebelah utara Bukit Tamalate. Umur satuan batupasir adalah Miosen Atas (Sukamto, 1975).

\section{Struktur Geologi}

Berdasarkan pengamatan terhadap permukaan, maka struktur geologi seperti sesar, perlipatan dan sebagainya tidak dijumpai. Penyebaran lapisan batupasir sebagai batuan dasar di daerah ini mempunyai sudut kemiringan yang berkisar antara $2^{\circ}-5^{\circ}$ ke arah selatan dengan arah jurus baratlaut-tenggara.

\section{ili. Tinggalan Arkeologi}

Pengamatan terhadap peninggalan Arkeologi Islam dimulai sejak tahun 1948, dengan meneliti makam-makam di Bontobiraeng. Tamalate dan Tallo. Yang menarik perhatian bagi peneliti arkeologi adalah kubur-kubur dan nisan yang bercorak unik, mengingatkan pada bentuk keris dengan hiasan yang menunjukkan unsur mega. litik. Sebagai contoh, batu nisan yang mempu-nyai relief bercorak tameng, dan diatasnya ter-dapat hiasan yang bertuliskan huruf Arab dengan isi syahadat (Tjandrasasmita, 1977).

Kerajaan Gowa dan Tallo terletak pada garis lintas perekonomian, khususnya pelayaran antara Indonesia bagian barat dan indonesia bagian timur dengan jenis komoditi yang berbeda. Hal ini mendorong perkembangan Kerajaan Gowa dan Tallo sebagai kerajaan mempunyai peranan penting. Perkembangan tersebut tidak terbatas sebagai pelabuhan niaga yang besar, tetapi Kerajaan Gowa telah pula mengembangkan kekuasaan politiknya ke wilayah lain. Hal ini menyangkut pula kepentingan pedagang asing dari Asia maupun dari Eropah Barat. Perkembangan hubungan laut ini membuka pula perkembangan kehidupan keagamaan di Kerajaan Gowa dan Tallo, dan pada tahun $1605 \mathrm{M}$, agama Islam secara formal menjadi agama Kerajaan (Nurhadi, 1978).

Pengkajian dan inventarisasi data kepurbakalaan yang telah dilakukan oleh Nurhadi (1978) terhadap peninggalan Kerajaan Gowa dan Tallo adalah sebagai berikut:

\section{Benteng Tua}

Lokasi ini pada bagian utara merupakan dataran rendah dan bagian selatan daerah perbukitan. Tinggalan arkeologi adalah sebagai berikut.

a. Bangunan Benteng Tua

Semula pembangunan benteng hanya mem. pergunakan tanah yang digundukkan meman. jang saja, beberapa periode berikutnya bangunan diperkuat dengan batubata. Pada penelusuran untuk mengetahui tempat penggalian dan penggilingan batubata untuk bahan bangunan ternyata tidak ditemukan.

b. Kompleks Makam Arupalaka

Seluruh dinding bangunan kubur dibuat dari batukapur, dengan perekat dari campuran bahan kapur dan pasir. Nisan-nisan dalam kompleks makam Arupalaka dibuat dari batupasir.

c. Kompleks Makam Sultan Hasanuddin Kepurbakalaan yang ada di Kompleks. Makam Sultan Hasanuddin, jirat dan nisannya terbuat dari batupasir, sedang jirat-jirat semu dari kuburan raja Gowa terdahulu dibuat dari batukapur. 
Batu Pelantikan, terietak \pm 150 meter di sebeah tenggara makam Sultan Hasanuddin. Jenis batu pelantikan andesit yang diapit dengan dua batu kapur.

Bungung Bissu, terletak di sebelah baratdaya makam Sultan Hasanuddin ( $\pm 175 \mathrm{~m}$ ). Bangunan ini terbuat dari batubata yang disusun tanpa spesi. Sekitar $50 \mathrm{~m}$ sebelah barat Bungung Bissu terdapat sebuah batu yang dikeramatkan sebagai tempat Tumanurung, yang kelak menjadi cikal bakal raja-raja Gowa. Tempat ini ditandai dengan sebuah batu andesit.

Bungung Lompowa, terletak $\pm 100 \mathrm{~m}$ di sebelah baratlaut makam Sultan Hasanuddin. Semua bagian sumur terdiri dari susunan balok batu kapur yang disusun/direkat dengan spesi Kompleks Makam Sultan Hasanuddin, terlihat.

\section{Benteng Anak Gowa}

Terietak pada dataran aluvial dan berjarak 2 $\mathrm{km}$ dari benteng tua, serta berada di sebelah ba. rat Sungguminasa. Bahan bangunan yang dipergunakan untuk pembuatan benteng tua adalah batubata.

\section{Benteng dan Pemukiman Somba Opu}

Lokasi ini terletak pada dataran aluvial yang sejajar dengan alur sungai Beru. Bangunan ini terbuat dari batubata.

\section{Benteng Dan Pemukiman Panakkukang}

Lokasi ini terletak pada dataran aluvial dan terletak di anak sungai yang bermuara di Sungai Beru. Bahan penyusun benteng dan pemukiman adalah batubata yang dapat terlihat dari sisi barat bekas benteng tersebut. Menurut penduduk setempat, terdapat jalur susunan batubata yang membentuk semacam tembok benteng dan menghubungkan Benteng Panakkukang dengan benteng Somba Obu. Jalur tembok ini menem-bus Desa Bayoa dan Garassi. Di Desa Bayoa ditemukan pecahan batubata yang tidak menunjuk. kan adanya susunan bangunan. Garassi terletak pada tebing selatan Sungai Beru, yang terlinat jelas pada singkapan tanah tebing sungai. Desa Barombong disebutkan sebagai pelabuhan Gowa dan terletak di sebelah selatan Panakkukang. Pada penelitian di desa ini tidak memperoleh adanya petunjuk bekas pemukiman kuno, dan harus pula dipertimbangkan pesatnya sedimentasi dan perubahan garis pantai di perairan ini.

\section{Benteng, Makam, dan Pemukiman Kerajaan Tallo}

Lokasi ini terletak pada dataran aluvial. Bahan bangunan adalah batubata, batupasir dan batu karang. Jirat-jirat semu pada makam di kompleks ini terbuat dari batupasir berbentuk balok disusun tanpa menggunakan perekat.

\section{Pemanfaatan Sumber Bahan Batuan}

Berdasarkan hasil analisis petrologi. baik terhadap batuan penyiusun wilayah Kerajaan Gowa dan Tallo maupun terhadap batuan yang dimanfaatkan untuk pembangunan tinggalan arkeologi, maka bahan batuan dan lokasi pengambilannya dapat diuraikan sebagai berikut.

\section{Lempung}

Lempung yang digunakan sebagal bahan dasar/baku untuk pembuatan batubata dan gerabah diambil dari daerah di sekitar muara Sungai Jeneberang, Panakkukang, Mangasa, Tallo dan Limbung. Batubata ini digunakan sebagai tem-bok benteng, dinding sumur bungung bissu jar, makam di bangunan benteng tua serta benteng anak Gowa, benteng dan pemukiman Somba Opu serta benteng dan pemukiman Panakku-kang Sedangkan benteng, makam dan pemuki-man Kerajaan Tallo, lempungnya diambilkan darı daerah Bulurokeng dan Tallo.

\section{Batu Pasir}

Batupasir yang diambilkan dari daeran $\mathrm{Pa}$ naikang. Tello, sebelah utara Tamalanrea, sebelah utara Bukit Tamalate. Bahan baku ini dipergunakan untuk pembuatan jirat dan nisan di makam Sultan Hasanuddin, nisan di kompleks makam Arupalakka, benteng dan pemukiman di Kerajaan Tallo.

\section{Andesit}

Batuan beku andesit terdapat sebagai fragmen dari breksi vulkanik pada satuan batuan gunungapi. Andesit ini dipergunakan sebagai tempat pelantikan dan sebagai tanda tempat Tumanurung. Kedua tempat tersebut termasuk datam kompleks makam Sultan Hasanuddin. Batuan beku andesit adalah batuan yang insitu dan tersingkap karena proses erosi

\section{Batu Kapur}

Batu kapur lebih dikenai dengan nama batugamping diambil dari daerah Maros dan Pangkep. Penggunaan batu kapur adalah untuk pembuatan jirat semu dan nisan untuk makam rajaraja Gowa sebelum Sultan Hasanuddin naik tahta. Sedangkan penggunaan lainnya adalah sebagai pendamping dari batu pelantikan. Selain itu, dipergunakan untuk pembuatan dinding sumur di Bungungbarania. Semua kepurbakalaan ini terletak di kompleks makam Sultan Hasanuddin.

\section{Batu Karang}


Batu karang atau terumbu karang (coral reef) termasuk organisme yang mempunyai syaratsyarat kehidupan tertentu. Terumbu karang ini diambil dari daerah sekitar perairan selat Makassar dan dipergunakan untuk pembuatan benteng, makam dan pemukiman Kerajaan Tallo.

\section{Penutup}

Daerah Ujung Pandang dan sekitarnya, bermorfologi dataran di bagian barat, makin ke-timur merupakan daerah perbukitan Satuan batuan penyusun adalah endapan aluvium, satuan batuan gunungapi, dan satuan batupasir, tidak dijumpai adanya struktur geologi.

Kepurbakalaan yang telah diteliti adalah, benteng tua, benteng anak gowa, benteng dan pemukiman Somba Opu, benteng dan pemukiman Panakkukang, benteng, makam dan pemukiman Kerajaan Tallo

Bahan bangunan yang dipergunakan untuk pembangunan kepurbakalaan adalah, lempung. batu pasir, andesit, batu kapur, dan batu karang. Semua bahan bangunan diambil dari sekitar pusat kerajaan, kecuali batu kapur diambil dari Maros dan Pangkep, sedangkan batu karang diam-bil di perairan seiat Makassar.

Pemindahan ibukota kerajaan dari kompleks benteng tua ke wilayah Somba Opu dengan alasan strategis, menimbulkan suatu dampak positif, yaitu pembangunan ibukota kerajaan yang baru perlu dilaksanakan. Pemindahan dan pembangunan ibukota kerajaan dengan alasan strategis dengan tidak strategis, menimbulkan suatu penafsiran tersendiri, yang pada akhirnya penulis tidak sependapat dengan alasan tersebut. Tidak diterimanya alasan itu, karena di sebelah barat wilayah Kerajaan Gowa dan Tallo merupakan morfologi dataran sedangkan di sebelah timur morfologi perbukitan. Selain itu, apabila dihubungkan data arkeologi dengan data geologi di daerah Ujung Pandang dan sekitarnya sebagai pusat Ke-rajaan Gowa dan Tallo, maka pembangunan kepurbakalaan tersebut lebih cenderung disebabkan karena bahan baku untuk pembangunan kepurbakaiaan banyak tersedia di sekitar pusat kerajaan tersebut.

\section{KEPUSTAKAAN}

Intan,S.Fadhlan M,dkk. 1979.Data Dasar Geologi Untuk Pengembangan Kotamadya Ujung Pandang Proyek NKK-UNHAS Ujung Pandang

1979.DAS Jeneberang Proyek Seminar Akademik UNHAS Ujung Pandang
1994. Dari Luwu, Agama Islam Menyebar Di Sulawesi Selatan Harian Pedoman Rakyat 20Nopember hlm. 10 Ujung Pandang

Lobeck,A.K. 1939.Geomorphology, An Introduc-tion To The Study of Landscape. Mc Graw Hill Book Company inc. New York and London, fig 182

Nurhadi,dkk.1980.Laporan Penelitian KepurbakaIaan Kerajaan Gowa dan Tallo di Sulawesi Selatan. BPA No. 26, Proyek Penelitian dan Penggalian Purbakala, Jakarta.

Nurhadi,1982. Pengamatan Penempatan Bahan Bangunan Dalam Penelitian Perubahan Desain Arsitektural Lokakarya Arkeologi, Proyek Penelitian Arkeologi Nasional, Jakarta, him. 143-149

Sukamto.R.,1975. Peta Geologi Lembar Ujung Pandang Puslitbang Geologi, Bandung

Thornbury,WD.1964.Priciple of Geomorphology New York, London, John Willey and Sons, Inc. fig. 100-152.

Tjandrasasmita.U.1977. Riwayat Penelitian Kepurbakalaan Islam di Indonesia, 50 tahun Lembaga Purbakala dan Peninggalan Nasional 1913-1963. Pusat Penelitian Purbakala \& Peninggalan Nasional, Jakarta. him 107-135. 